reasons why it is now possible for commercial nuclear power stations to be built near towns, and must also be a strong selling point abroad.

Smaller models of the Dungeness $B$ vessel, made to a scale of about 1 to 26 , have already been successfully tested at Heston. 'These models were shown to have a failure pressure more than three times greater than the design prossurc for the Dungeness vessel. On the larger scale models, the CEGB requires a safety factor of 2.5 , which APC is confident of achieving. Testing will consist first of elastic tests up to the proof pressure of 550 pounds per square inch, which is 15 per cent greater than the design pressure. The process of testing involves more than 300 gauges built into the fabric of the pressure vessel. Once the elastic tests have been completed satisfactorily, the vessel will be tested to destruction. At failure, the vessel begins to crack without exploding violently-either the steel reinforcement can fail, or some parts of the concrete fail under compressive loading. In either case, the failure can be followed on the strain gauges. The actual vessel at Dungeness $B$ will have even more gauges, and will itself have to be tested when it is complete, but only to the proof pressure.

\section{ELDO Escalates}

The ELDO conference of ministers met in Paris last week to discuss what is to be done about the rising cost of the development of a European launcher. The overspending, which primarily concerns the project to build a rocket capable of launching a European communications satellite in the early 1970 s, is expected to reach $\$ 100$ million. A revised version of the programme which should cut this figure to $\$ 50$ million was favoured by the conference, and all the ELDO countries, with the exception of Britain, stated their willingness to pay the excess. The British delegate reiterated the announcement made in April that, once Britain had paid its share of 27 per cent of the original estimate of the cost of ELDO, it would make no further contributions. This means that Britain is not going to help pay the extra $\$ 50$ million either. Other members urged Britain to join them in finding the extra money, but their pleas do not seem to have softened the British stand.

Britain was not the only country unhappy about the situation. Italy was worried that the revised programme would mean less interesting work for them to do. Both ETDO and ESRO have been plagued by this kind of problem, which is a result of the distribution of contracts among the member states, and this question is to be looked into before the next meeting. Germany and France were anxious about the effect the revised programme would have on their plans to launch the Symphonie communications satellite, while Belgium said the new plan should be part of a coherent and integrated European space effort. The outcome of all this seems to have been to leave things as they are, with a promise to look into the problems before the next session.

\section{Student Housing}

'THE chief requirement for student housing is privacy; this is the implication of a recent survey of residents-
92 per cent students-in eight recent housing schemes (Building Research Station, IIostel User Study). Only 10 per cent of the students in single rooms would even consider sharing, and those who did share expected a considerable reduction in rent, both to compensate for the inconvenience and to prevent the landlord from benefiting financially from the double rent.

Single room sizes in the schemes vary from 96 to 144 square feet, with rooms between 125 to 135 square feet acceptable to more than 90 per cent of the residents. The survey concluded that 95 foot square rooms were suitable for short stays or the "single girl's first time away from home", while rooms above 110 feet square wcre large enough for general use by all students. Some individual control over both lighting and heating seemed to be necessary to most of the students and the survey urged that lighting be brought up to recommended standards as quickly as possible.

Common rooms were inadequate in most of the schemes studied, especially rooms where music could be played. One scheme with only one games roomone dart board and one table-tennis table-for 504 students was hardly used at all, probably from a sense of hopelessness. While common rooms for television, meetings and entertaining were used by most residents, students and management both welcomed the possibility of breaking down residence facilities into smaller units of up to twenty-five people each, with their own lobby, entrance and kitchen-common room.

The problems of student housing in overcrowded cities such as London as well as in the new universities and colleges means that much more research needs to be carried out on student needs. As this survey points out, "young people coming into accommodation provided for them expect room standards higher than those they are prepared to accept in lodgings and flatlets that they find for themselves".

\section{Director Appointed}

Dr Gordon Frank Claringbull will direct the British Museum (Natural History) from December I when Sir Terence Morrison-Scott retires. His appointment by the trustees after an open competition is one from the museum ranks - Dr Claringbull has been the keeper of the Department of Mineralogy since 1953 and a member of the museum staff since 1935. This should appcase the Museums Association and others who expressed displeasure at the appointment of an outsider to the directorship of the British Museum.

The director of the Natural History Museum, though responsible to the trustees for all matters concerning the management of the museum, is at the same time the accounting officer and is directly responsible to Parliament for the funds voted to the trustees$£ 1,011,000$ for the year $1968-69$. This dual responsibility means that the trustees have to get the Prime Minister's approval before they can announce the appointment of a new director.

Dr Claringbull will head a staff of about 600 , of whom around 350 are scientific staff. They are not strictly civil servants, as they are appointed and employed by the trustees, but for all practical purposes they are treated as civil servants. Another peculiarity is that, since 1946, the scientific staff have been on scientific civil service gradings, the keeper class being 
fitted into the scientific officer scale. This means that, unlike the directors of other national museums, the director is graded as a chief scientific officer. This does not seem to affect his salary one way or another; he will get a salary of $£ 5,375$, which seems to be the same as the salaries of the directors of, for example, the Science Museum and the Victoria and Albert Museum. The director and principal librarian of the British Museum naturally receives a little more-he gets $£ 5,550$, and is responsible to the trustees for managing

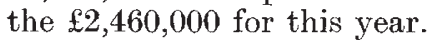

\section{Brains and Behaviour}

European students of the brain tend to meet each other most often at conferences held in the United States. There is at present no organization equipped to convene regular symposia on the brain in Europe, where meetings would be cheaper and more frequent, and Europeans who work in the field have come to feel out of touch with one another's work.

To repair this lack of communication it is proposed to form a European Brain and Behaviour Society. The present intention of the society is "to further scientific enquiry within those fields that bear on the interrelationships between brain and behaviour"; to this end it will hold meetings for discussion and the reading of papers and disseminate information. A study group is to meet in Rotterdam early next year to define further the aims of the society and to elect its first membership. All persons interested in joining are invited to write to Dr A. Cowey at the Institute of Experimental Psychology, South Parks Road, Oxford, stating their field of interest and qualifications, together with any suggestions they may have about the general aims of the society.

The idea of the society originated in a meeting of scientists called by the Organization for Economic Cooperation and Development (OECD) last year to discuss the field of the neurosciences. The opinion at the meeting was that organizational facilities in Europe were poorly equipped to support the expansion of what is considered to be a fast growing subject. The sponsors of the proposed society are K. Akert (Zurich), A. Cowey (Oxford), M. Frankenhaeuser (Stockholm) H. G. J. M. Kuypers (Rotterdam), J. Paillard (Marseilles), D. Ploog (Munich), J. Scherrer (Paris) and L. Weiskrantz (Oxford).

\section{Spectacles for Life}

A PAIR of variable refraction spectacles has been developed by $\mathrm{Dr}$ B. M. Wright of the Engineering Division at the National Institute for Medical Research at Mill Hill. Instead of the conventional solid lenses of existing spectacles, the lenses are hollow, with thin flexible walls, and are filled with a nearly saturated solution of calcium bromide which has a suitable refractive index. The volume of the lenses is changed by pumping the liquid in and out in order to change the curvature of the flexible wall. This is accomplished by means of a simple cylinder and piston with a rubber ring seal. The piston is operated by a slide in one side piece of the spectacles, the cylinder being housed in a cavity on the inside. Because these spectacles can be continuously adjusted as the need arises, one pair should, in theory, last a lifetime, and should therefore be much cheaper than existing spectacles. Dr Wright has been wearing a pair of these spectacles for more than three months with no complaints, but their durability remains to be proved.

This was one of the exhibits at a recent visit to the institute. In the Division of Parasitology, Drs S. R. Smithers, R. J. Terry and D. J. Hickley claim to have discovered how the parasite causing schistosomiasis avoids rejection by the human body. Using immunological techniques, they have shown that the parasite somehow sticks host antigenic material onto itself so that it is not recognized as "non-self" by circulating antibodies. According to the three research workers, this "disguising" phenomenon may explain why the parasite can persist in the human body for up to 20 years in what ought to be an immunologically hostile environment.

An interesting proposal for the structure of ribosomes was put forward by Dr R. A. Cox, who illustrated his talk with models built within the department. Sir Peter Medawar, director at Mill Hill, hopes to see a department at the institute which correlates physiology of the central nervous system with behaviour. Because, however, different animals have been used so far for behavioural studies from the ones used for physiological studies, Dr B. Delisle Burns has a difficult task ahead. At present, he and other members of the Division of Physiology and Pharmacology are studying the way in which neurones in the brain respond to patterns of light falling on the eyes. Information about the disturbance set up in the brain in this way could prove useful to the practice of ophthamology, particularly in connexion with the treatment of strabismus-or, put more plainly, squint.

\section{Accident Prevention}

More than 7,000 people died in traffic accidents last year in Britain and nearly 94,000 were seriously injured, with the numbers increasing more quickly than the mileage travelled. The causes and possibie preventive measures were the subject of a recent conference at Cranfield on vehicle and road design, sponsored jointly by the Institution of Mechanical Engineers and the Advanced School of Automobile Engineering. This is one of the few occasions on which vehicle and road designers have met to discuss their common problem-the car and its driver.

A police traffic superintendent is reported to have said that the defect which causes nearly every accident lies in "the nut holding the wheel". One contributor pointed out that road engineers should not assume that drivers are omniscient. "If asked to make more than one decision at a time, they will fail; if' faced with a situation which can be misinterpreted, someone will eventually find the wrong meaning."

The effect of human fallibility is easily apparent in the statistics for traffic accidents during the last three months of 1967 in Britain, after the breathalyser test came into operation; during this period, driver and passenger casualties fell by 19 per cent, motor cyclist casualties by 16 per cent and pedal cyclists by 14 per cent. But drivers are not altogether to blame; nearly half of all serious accidents in Britain take place at uncontrolled junctions, and at some intersections accidents have fallen by 40 per cent when traffic lights have been installed. Professor R. J. Smeed of University 